\title{
OFFSHORE INVESTMENTS-CUI PRODIS? SCHRÖDINGER'S CAT IN OFFSHORE FINANCING: BOTH ALIVE AND DEAD
}

\begin{abstract}
Trends of FDI in offshore tax havens were compared to efforts and efficiency of regulatory authorities to prevent money laundering. Based on available data it was stated that current position in offshore FDI stays alive and officially dead at the same time, keeping the balance of interests for the main stakeholders: corporations, authorities and financial institutes support further offshore investments. Analysis based on volumes of trade and financial transactions between offshore centers, developed and developing countries. As a result withdrawal of financial resources from the developing countries degrades social capital funding and supports corruption growth.
\end{abstract}

Key words: FDI, money laundering, offshore financing, offshore investment, tax havens

\section{Introduction}

Years of struggling with the illegal capital flow to tax havens resulted in numerous legal restrictions, law enforcement, FATF-GAFI regulations, declaring in 2008 that all the suspicious offshore jurisdictions are "clean", and an offshore capital pie is doubling in 10 years. Under modest Boston Consulting Group estimates the main offshore investments have sized more than 7.5 trillion, the more severe evaluations were made by James S. Henry, states it is about 21-33 trillion. (Don't ask, won't tell, 2012) (Henry, 2012) The total direct and indirect losses associated with the withdrawal of assets from the budgets of the countries, comparing to an annual global GDP- $\$ 70$ trillion and the average share of state budgets in the national GDP- about 40-50\%, then "grey zone" of economies accounts for at least $10-12 \%$ of budget expenditures. This is roughly the same amount spent on the reproduction of social capital (health and education) in the countries. "After over 20 years of money laundering prevention, the results are disappointing: Organized crime and drug trafficking still prosper. Banks face a high burden because of their active involvement in money laundering prevention. The

Anna Stepuk, Higher School of Economics, Moscow, Russia, e-mail: anna.stepuk@ gmail.com 
various prevention schemes have weakened the basic rights of the bank clients, who have to pay for the prevention measures." (Hans and Wuensch, 2006, p. 37)

The reason why offshore jurisdictions still exist and what is the final destination for the infinite stream of laundered money - these questions were answered in the paper by the example of two neighboring countries: Russia and Ukraine, several Group of Eight countries (Germany, United States of America and United Kingdom) and one of the leaders among developed countries in attractiveness for the offshore investments - Switzerland.

The main reasons for investing in offshore areas: tax planning, international trade and economic cooperation, protection of assets from creditors or derived from illegal activities (arms trade, drug trafficking), switching of jurisdiction to resolve legal disputes, if incomes, obtained as a result of locally restricted activities (corruption or insider trading), to improve the efficiency of resources allocation by investors contrary to the existing budget expenditures in donor countries. Of the above the majors in referenced countries are tax evasion and asset protection, disregarding crime activity. (Kar and Freitas, 2013)

Money laundering has a disastrous influence on economics, political and social situations in all the countries. According to "Multidisciplinary Economics of Money Laundering" by J. Ferwerda (Ferwerda, 2012), negative economic effect appears in decreased investment appeal, unfair competition between honest and dishonest business, distortion of prices and eventually the crowding out of honest business; political effect appears in disruption of the democratic systems by criminals (for example, drug dealers to be appointed to a high public post); social effect - increased corruption and business crime. But at the same time money laundering provides billion dollars investments in European banking system which result in additional loans for consumers and businesses, especially during financial crisis, and liquidity growth. So the question is whether money laundering harms anyone, and if it is, who are the victims and what amount of money would be enough to cover all the problems, caused by it, and to become beneficial for the developed countries' banking systems and economics.

Estimates of global amounts of money laundering vary from 2 to 5\% of GDP (John Walker, 1995, 2.8 trillion US\$, Michael Camdessus, 1998, 1.5 trillion US\$, Buehn and Schneider, 2006, 603 billion US\$, 1.74\% US GDP). Till the nowadays disputes on growth or decline and volumes of money laundering stay unresolved.

To keep consistency of the below analysis in my paper, cash flows volumes are mainly estimated according to official data (i.e. Central Banks, Federal Reserve System and Deutsche Bundesbank data). The data then used to answer the question whether offshore jurisdictions would exist and for whom money laundering is beneficial and whom it harms. In order to answer these questions this paper is divided in three sections: the impact on developed countries (USA, UK, Germany and Switzerland), developing countries (Russia and Ukraine) and comparison of the effect of money laundering consequences on all these countries. 


\section{Developed contries}

In the developed countries, outflow offshore investments lead to the reduced tax revenues and the budget detriment. As a result offshore investments originated from those countries are rigorously scrutinized by authorities. (Gravell, 2013) For example, a 2013 U.S. law comes into force - Foreign Account Tax Compliance Act (FATCA), under which foreign financial institutions will be required to monitor the payment of taxes to U.S. customers and report to the U.S. $\operatorname{tax}$ authorities. In case of failure of these institutions will be forced to pay $30 \% \operatorname{tax}$ on their investments in the U.S.

Figure 1: Turnover by currency (BIS, 2013, p. 7)

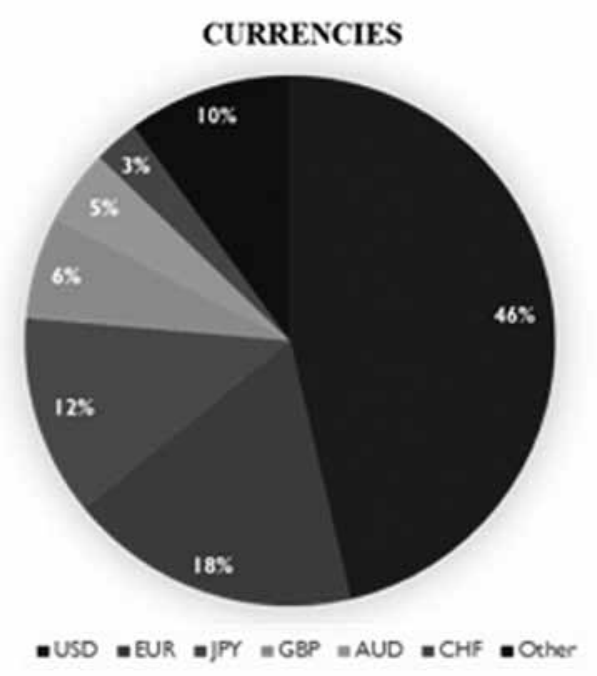

On the other hand, offshore investments made by the developing countries contribute to the budget of the developed countries due to the surplus of an external capital (1.2 trillion), profiting from its allocation in the domestic market, geography of offshore zones and investing in the major convertible currencies. Most of the calculations are carried out in offshore areas, usually in major convertible currencies: U.S. dollars, euros, pounds, Swiss francs et al. According to the Triennial Central Bank Survey from September 2013 (Figure 1), the most traded currency are: USD (United Stated dollar), EUR (euro), JPY (yen), GBP (pound sterling), AUD (Australian dollar) and CHF (Swiss franc) As a result, the offshore assets allocate in the correspondent accounts of banks in the countries issuing those currencies. This, in turn, increases the amount of credit available in these countries and their emission revenues. 
Figure 2: Germany FDI stock by countries and flows (Jost, 2013, p.7-10)

\section{GERMANY FDI stock}
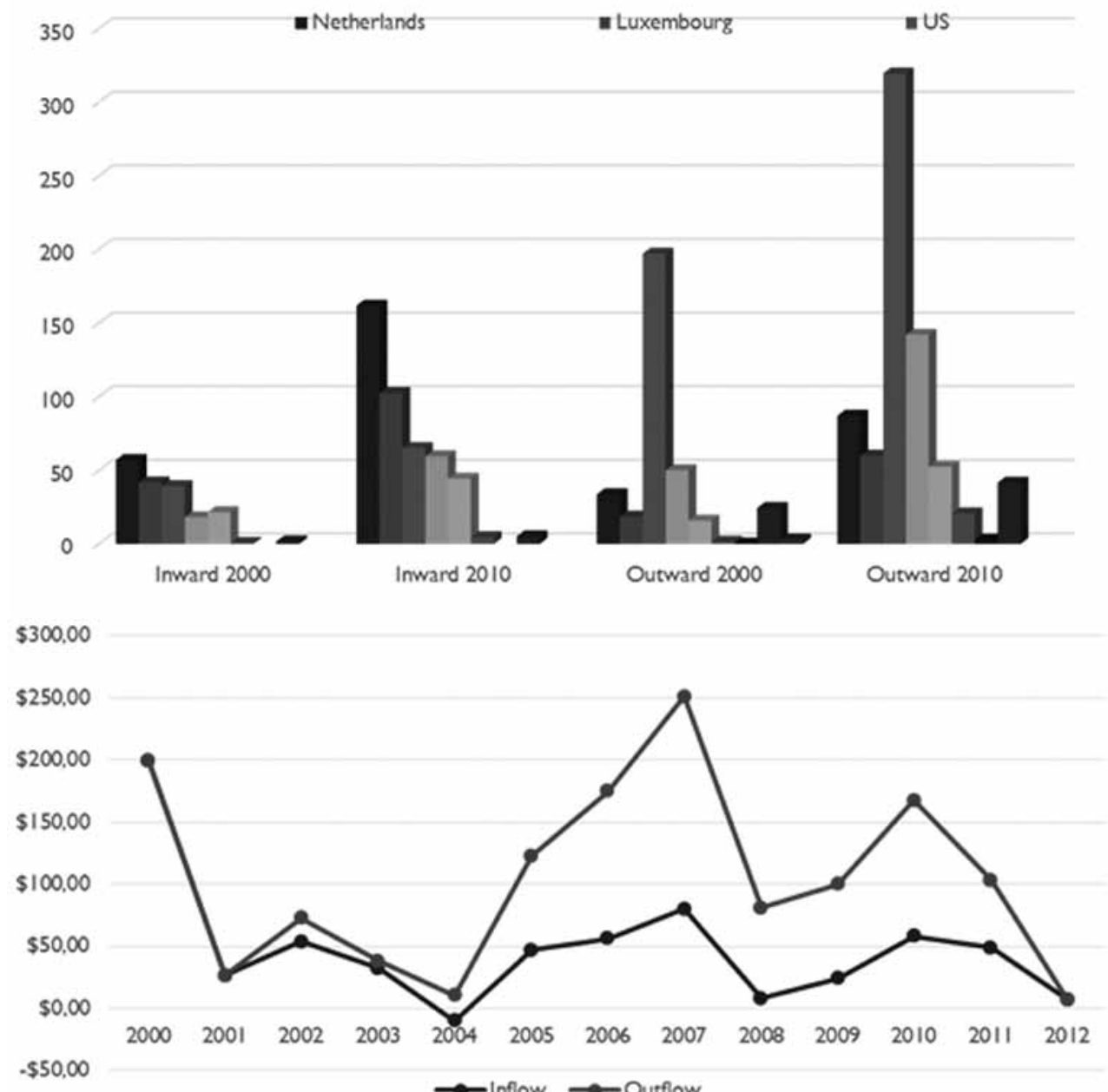

Another benefit from the money laundering to the developed countries could be seen from official FDI data: most of the beneficiaries prefer to have their money on deposits in strong and well-performed bank, i.e. in banks of the developed countries, for example Deutsche Bank, Barclays, JPMorgan, etc. They also prefer to invest in countries with stabilized and well-developed economics.

Investigation of capital flight in Germany gave us results, proving that money from offshore jurisdictions end up in developed countries. Great part of FDI inward Germany comes from Netherlands and Luxembourg, moreover this quantity is much more than these countries' GDP (additional material in Appendix).(Figure 2) 
Capital flight chart shows that cash flows in offshore jurisdiction are much higher that annual GDP in these countries. That fact brings us to the conclusion that money sent to these countries end up somewhere else. Negative account balance in developing countries and positive in developed (exc. US, which could be explained with Governmental debt) leads to making a suggestion that money laundered by investors of the developing countries do not come back to these countries and do not stay in offshore jurisdiction, but are sent to the developed countries, i.e. Germany, UK. (Figure 3)

Figure 3: Capital Flight (Smith, 2011)

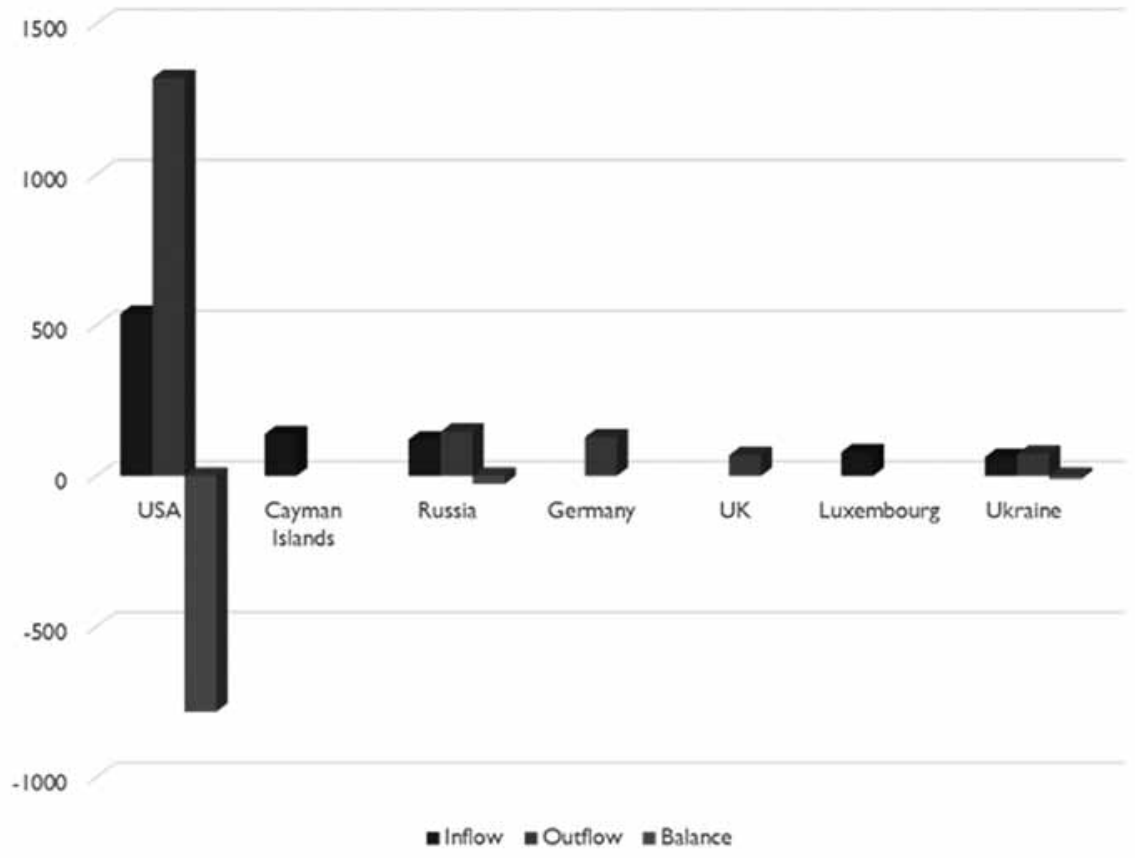

\section{Developing countries}

In developing countries, offshore investments also depress tax revenues. However, such investments improve efficiency of the assets protection, increase not taxable base, and profits from reinvesting the previously withdrawn capital as seen at the above draw. Reinvestment of offshore assets also raises investment attractiveness of the developing countries. The more important is that the "locally legal" capital, i.e. acquired as a result of "globally illegal" activities (corruption, insider trading, criminal offenses in the developed countries), can obtain legal guarantees of property rights in form of offshore investment. The owners of these investments gain an opportunity to appeal to independent judi- 
cial institutions for resolving property disputes, which are not dependent on the local authorities. That is the offshore investments from the developing countries are invigorated de-facto by any authorities.

These conclusions are observed comparing FDI stocks and FDI cash flow data in Chart 4 (for Russia, additional data could be found in Appendix): if the developed countries allocated their FDI in the same developed countries or new emerging markets, the developing countries put their FDI in offshore centers: to hide them away from own authorities and own population. The same concerns FDI cash flow: it's negative for the developed countries, because of their capital export to gain new markets and positive for the developing countries: so-called the «returning» laundered capital, which is times less than exported to FDI capital.

Figure 4: Russia FDI stock and flows (Kuznetsov, 2012)

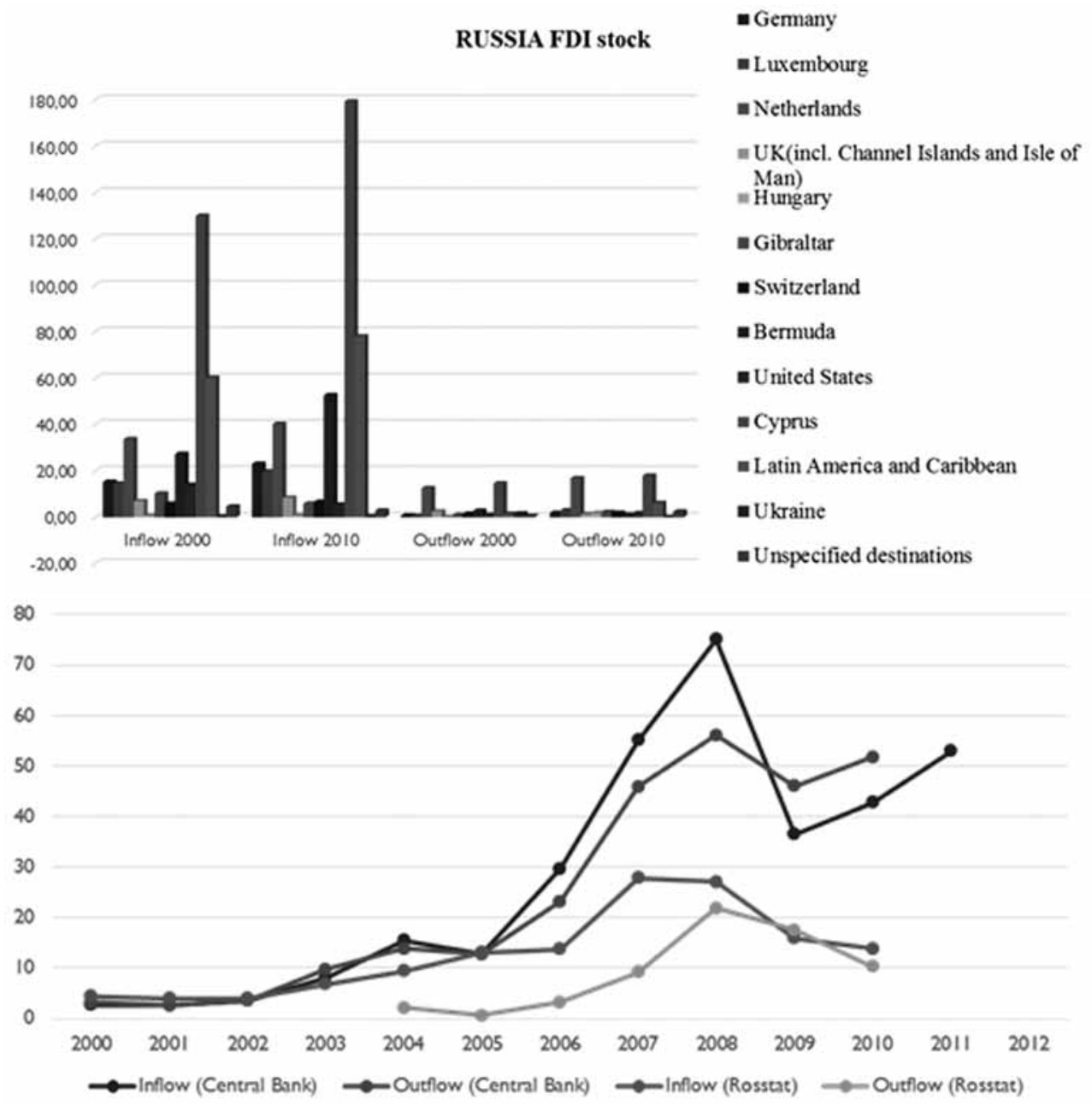


To make things «worse» in disclosing the details of transactions statistical data from the developing countries usually lack of transparency or artificially ambiguous transforming the problem their adequacy to famous Schroedinger cat paradox: half alive, half dead. For FDI example, there are two official sources statistics in Russia (Figure 4). Bank of Russia estimates FDI figures by using balance-of-payments data. As a result, it includes all forms of FDI. Its statistics are the source for the FDI data for Russia in UNCTAD's FDI database (though UNCTAD usually receives preliminary data for the latest year and updates it only in subsequent reports). However, the Bank of Russia's data lack detailed information on the sectorial structure of FDI. The Federal State Statistics Service (Rosstat) collects data from companies and publishes detailed information (since 2005). However, its data do not include information for some countries and industries because the level of transparency of some Russian MNEs is inadequate. The differences in times put under the question robustness of their integrity, especially comparing them to data collected from national statistics bureaus of host countries. If in Cyprus in 2010 outflow was 120,09; 13,15; 3,61, that is actually from 120 US\$ bln only 3,6 US\$ bln landed in Cyprus, then in Germany - vice versa 0,$11 ; 7,44$ and 2,93 or in Netherlands 12,$40 ; 24,11 ; 0,45$. (Figure 4) It means that capital nominally forwarded to Cyprus goes to alternative destinations, Germany is bad choice for money laundering, i.e. to cap «invoices" extra funds had to be transferred from other sources to fill the gap. The Netherlands illustrates its position as corporate holding best place - nominal transfers are not supported with actual capital inflow to the country.

\section{Comparison of developed and developing countries}

The developed countries apart from gaining advantage of inward outer financial resources extensively utilize tax loopholes while shifting profits to lowtax jurisdictions. The well-known example of the "double Irish, Dutch sandwich" scheme has been used by Google, Apple, Amazon, Facebook and Starbucks. In such cases an Irish holding company gain rights to sell advertising (Google's revenues) via its subsidiary, but between them established a Dutch company, which collects royalties. This scheme allows the Irish operator pay zero tax in its tax shell in Bermuda or the Cayman islands (Yahoo) and also, by using the Dutch sandwich, to avoid Irish withholding taxes. The data from the Report for Congress in January 2013 by Chief economist Jane G. Gravelle also provide comparison of US profits generated in tax havens with their GDP. "In three of the islands off the U.S. coast (in the Caribbean and Atlantic) profits are multiples of total GDP. In other jurisdictions they are a large share of output. These numbers clearly indicate that the profits in these countries do not appear to derive from economic motives related to productive inputs or markets, but 
rather reflect income easily transferred to low-tax jurisdictions". (Gravell, 2013) If US Company Profits Relative to GDP in G-7 countries has the weighted average $0.6 \%$, then in the Netherlands - $4.6 \%$, Luxembourg - $18 \%$, Bahamas - $43 \%$, Bermuda - 646\%, British Virgin Islands - 355\% and Cayman Islands - 546\%

So far, the developed countries gain two advantage-"free" outward financial resources and mechanism for tax optimisation. Oppositely the developing countries drain their money supply and tax revenue both together.

Figure 5: FDI capital transfers and trade based transfers normalized to GDP of the host countries (Federation, 2013) (The World Bank, 2013)

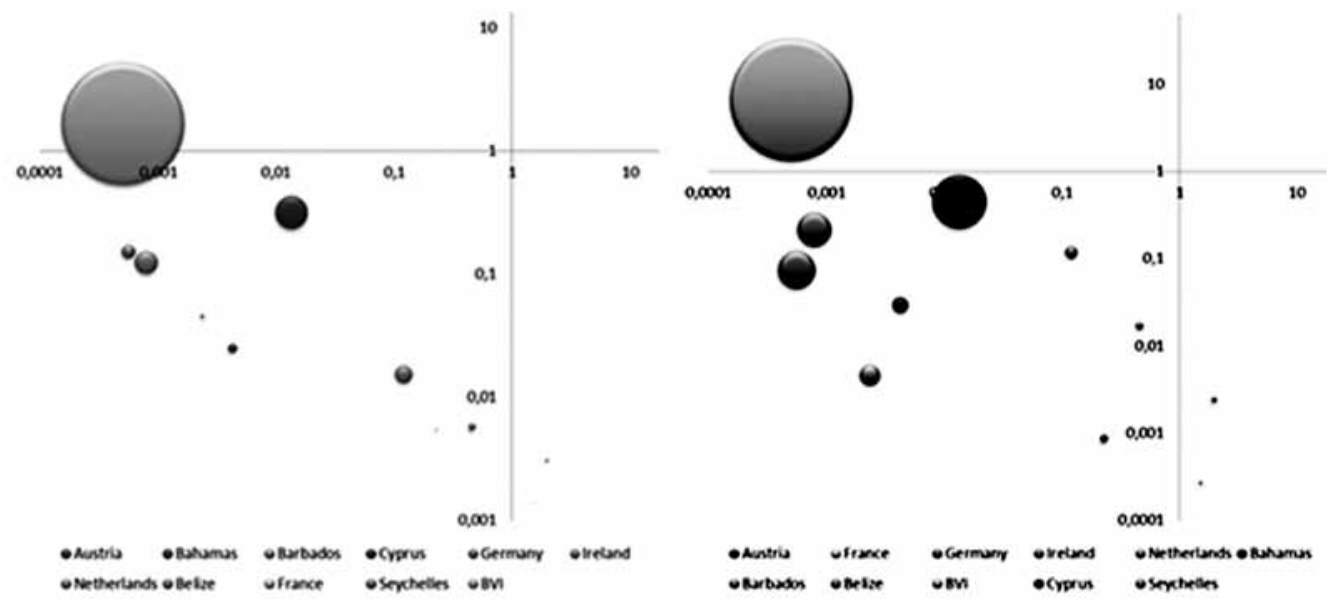

Utilizing the data of Central Bank of Russia, the drawn Figure 5 illustrates investment (FDI) capital (direct and portfolio investments) flows and trade based transfers normalized to GDP of the host countries. These figures clearly demonstrate abnormal distribution of funds transfers between offshore centres (Cyprus, BVI, Barbados, and Seychelles) and the developed countries (Austria, Germany, the Netherlands). Such way of presenting let outline the destination of "suspicious" transactions' destinations as graphical indicators for gravitational (Walker) money laundering framework.

\section{Conclusion}

Analysis of the presented data in capital flight, FDI stocks, the long lasting regulatory efforts to prevent money laundering or cleptocracy assets allocation combine together complex socio-economic task, which reminds in some way the famous Copenhagen interpretation (introduced by Niels Bohr in 1920) of coherent superposition in quantum mechanics and the famous Schrödinger's cat (suggested by Erwin Schrödinger in 1935) living in the box with radioactive 
material, hydrocyanic acid and a Geiger counter for detecting radiation. In this imaginary experiment the cat in the box could not be observed, and therefore it is hard to be said whether it was alive or dead. It's sort of superposition of life and death simultaneously. In the same manner they may say that, when cash flow is observed, its attribute (legality) is forced to take one state or another (licit or illicit), oppositely it's veiling with offshore secrecy then illegal financing becomes both alive and dead at the same time. Multiple sources of capital from heavy crimes to white collar kickbacks mixed with the legal funds together with the vested interests of key players: illegal capital businesses, corrupt authorities and financial institutes put under the question traditional ways of regulations.

There're three major findings of the made analysis. Firstly, balance of interests of the major stakeholders (authorities, transnational corporations and financial institutes) in developed and developing countries does support offshore investments both inward and outward. Secondly, referencing to volumes of trade and financial transactions, the developing countries are mostly donors, contrary to some of the developed countries or their dependent territories, some of which are recipients of offshore FDI. Thirdly, withdrawal of financial resources from the developing countries degrades their business and investment infrastructure, detoriates social capital and keeps corruption growth up.

But still, there're a lot of unsolved problems for further investigations. Is there any upper limit of the withdrawal of capital to the offshore jurisdictions from developing countries, which inevitably would lead to social collapse or disorder? How profitable are cash flows from offshore jurisdiction and allocation of offshore assets on correspondence accounts for developed countries' government.

Flight capital and money laundering still imply heavy costs on societies, which incudes in direct expenditures on AML, collateral damages for the society: a loss of privacy, use of common goods by criminals (transportation, education system, health care, legal institutes), economic damages: increases costs for using international financial system and discrimination in trade and co-operation.

\section{Literature}

- Anken, F. and Beasley, J.E. (2012). Corporate structure optimisation for multinational companies. Omega 40, 230-243.

- Arowosaiye, Y.I. (2009). The Devastating Impact of Money Laundering and other Economic and Financial Crimes on the Economy of Developing Countries: Nigeria as a Case Study. International Islamic University Malaysia.

- Baker, R.W. (2005). Capitalism's Achilles heel: dirty money and how to renew the free-market system.

- Bikker, J. et al.(2011). Gravity Models of Trade-based Money Laundering. DNB Working Paper, (318). 
- $\quad$ BIS, B.F. (2013). Foreign exchange turnover in April 2013: preliminary global results. Triennial Central Bank Survey.

- Buehn, A. and Schneider, F. (2011). A Preliminary Attempt to Estimate the Financial Flows of Transnational Crime Using the MIMICMethod. August.

- Brada, J.C., Drabek, Z. and Perez, F.M. (2012). Illicit money flows as motives for FDI. Journal of Comparative Economics, 40, 108-126

- Burrows, J., Fleming, M.H. and Levi, M. (2007). The Nature, Extent and Economic Impact of Fraud in the UK. Association of Chief Police Officers': Economic Crime Portfolio.

- Chaikin, D. and Sharman, J.C. (2009). Corruption and Money Laundering: A Symbiotic Relationship.

- Don't ask, won't tell. (2012). Retrieved 11.02.2012 from The Economist: http://www.economist.com/node/21547229.

- Driffield, N., Lancheros, S., Temouri, Y. and Zhou, Y. (2012). Inward FDI in the United Kingdom and its policy context. Vale Columbia Center.

- Ferwerda, J. (2012). The Multidisciplinary Economics of Money Laundering. Ridderkerk: Ridderprint.

- Geiger, H. and Wuensch, O. (2006). The Fight Against Money Laundering-An Economic Analysis of a Cost-Benefit Paradoxon. September.

- Gnutzmanna, H., McCarthyb, K.J. and Unger, B. (2010). Dancing with the devil: Country size and the incentive to tolerate money laundering. International Review of Law and Economics, 30, 244-252

- Gravell, J.G. (2013). Tax Havens: International Tax Avoidance and Evasion. Washington, DC: Congressinal Research Service.

- $\quad$ Guglger, P. and Tinguely, X. (2010). Swiss inward FDI and its policy context. Vale Columbia Center.

- Henry, S.J. (2012). The Price of Offshore Revisited. Tax Justice Network. July.

- Iacolino, S. Report on organised crime, corruption and money laundering: recommendations on action and initiatives to be taken (final report)/ European Parliament. Special committee on organised crime, corruption and money laundering. 2009 - 2014/Plenary sitting/A7-0307/2013/2 6.9.2013/2013/2107(INI).

- Jost, T. (2012). Inward FDI in Germany and its policy context. Columbia FDI Profiles.

- Kar, D. and Freitas, S. (2013). Russia: Illicit Financial Flows and the Role of the Underground Economy. Global Financial Integrity, Washington.

- Kononov, O. (2012). Inward FDI in Ukraine and its policy context. Vale Columbia Center.

- Kornecki, L. (2013). Inward FDI in the United States and its policy context. Vale Columbia Center.

- Kuznetsov, A. (2012). Inward FDI in Russia and its policy context. Vale Columbia Center. 
- Lilley, P. (2006). Dirty Dealing: The Untold Truth about Global Money Laundering, International Crime and Terrorism. London. Retrieved from DirtyDealing.

- $\quad$ Linde, D.V. and Unger, B. (2013). Research Handbook on Money Laundering. Cheltenham: Edward Elgar Publishing Limited.

- Mauro, P. (1999). The Effects of Corruption on Growth, Investment, and Government Expenditure: A Cross-Country Analysis. Institute of International Economics, Corruption and the Global Economy.

- McDowell, J. and Novis, G. (2001). The Consequencies of Money Laundering and Financial Crime. Money Laundering-Economic PerspectivesState Department Bureau of International Narcotics and Law Enforcement Affairs. U.S. Department of State. May.

- Picard, P.M. and Pieretti, P. (2011). Bank secrecy, illicit money and offshore financial centers. CREA, University of Luxembourg, Luxembourg. Journal of Public Economics, 95, 942-955.

- Schwarz, P. (2011). Money launderers and tax havens: Two sides of the same coin? International Review of Law and Economics, 31, 37-47.

- Smith, D. (2011). Black Money: The Business of Money Laundering. Retrieved 7.06.2011 from Economy Watch: http://www.economywatch.com/ economy-business-and-finance-news/black-money-the-business-of-money-laundering.08-06.html.

- The Other Side of the Coin: The UK and Corruption in Africa. (2006). Africa All Party Parllamentary Group.

- Unger, B. and Walker, J. (2009). Measuring Global Money Laundering: "The Walker Gravity Model". University of Wollongong, Australia. Utrecht University School of Economics.

- Walker, J. (2007). Measuring Global laundering. Utrecht: Presentation at Utrecht School of Economics. November. 
APPENDIX (Driffield, Lancheros, Temouri and Zhou, 2012) Kornecki, 2013) (Kononov, 2012) (Guglger and Tinguely, 2010)

\section{UK FDI stock}

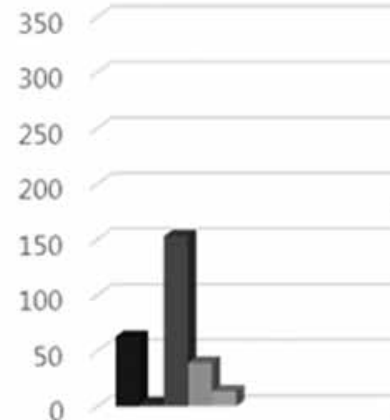

Inward 2000

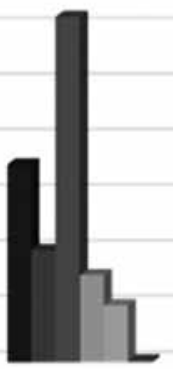

Inward 2010

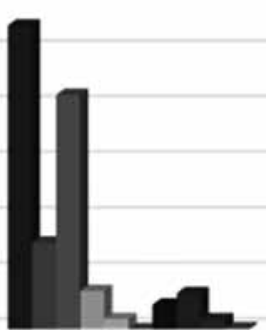

Outward 2000

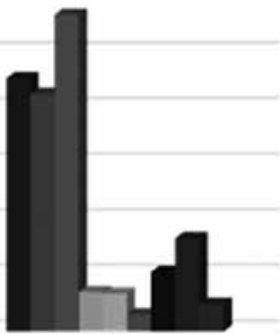

Outward 2010
- Netherlands

aUS

m Switzerland

- UK Offshore Islands

- Bermuda
- Luxembourg

= Germany

m Russia

- Latin America and the Carribean

- Gulf Arabian countries

\section{UK}

\section{0 \\ 450 \\ 400 \\ 350 \\ 300 \\ 250 \\ 200 \\ 150 \\ 100 \\ 50 \\ 0}

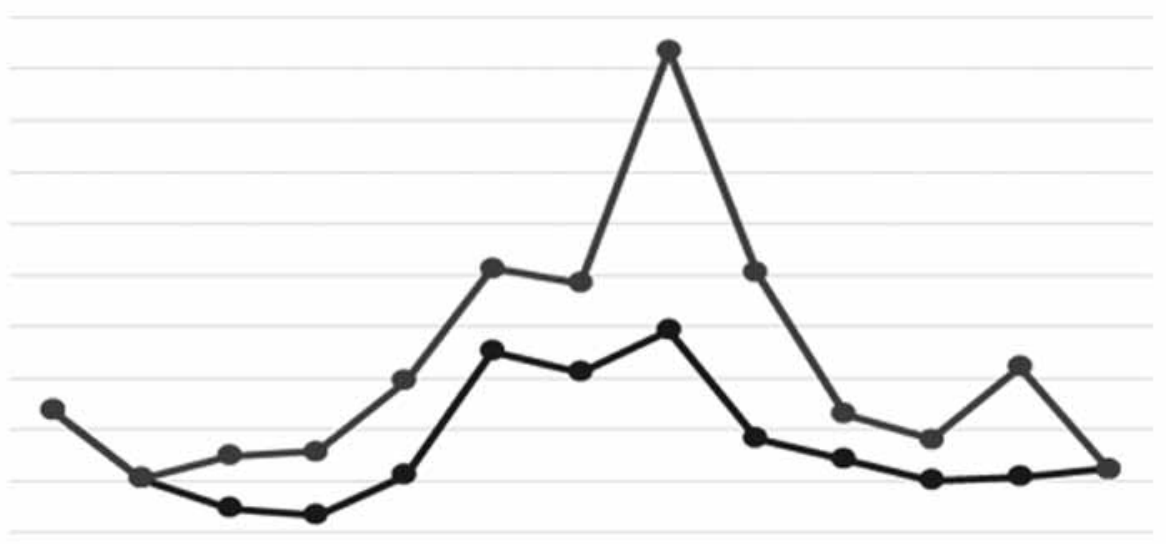

2000200120022003200420052006200720082009201020112012

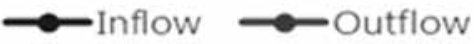




\section{US FDI stock}

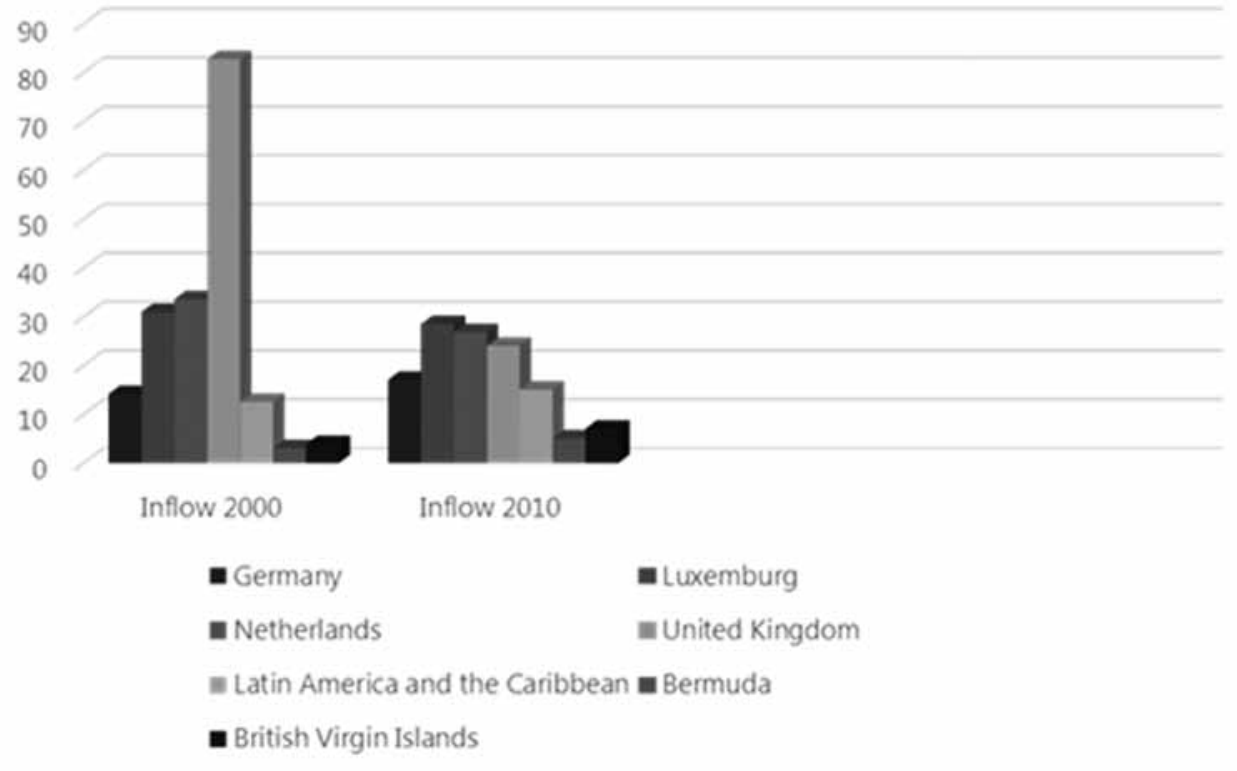

\section{US}

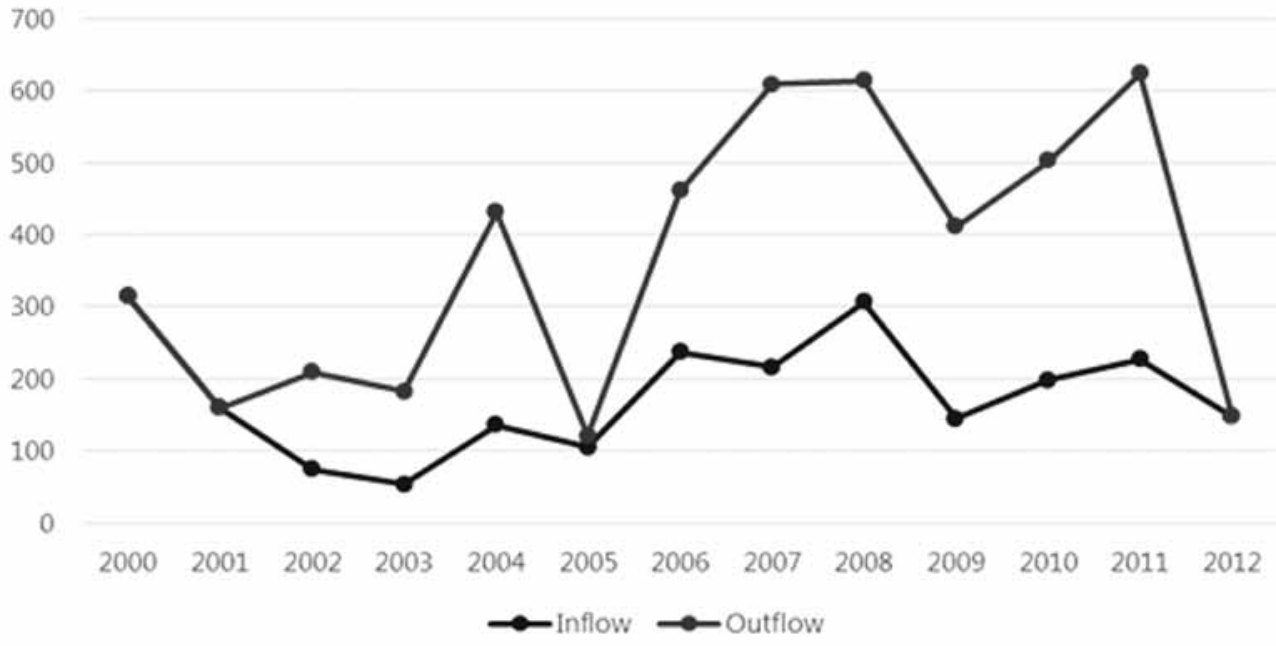




\section{UKRAINE FDI stock}

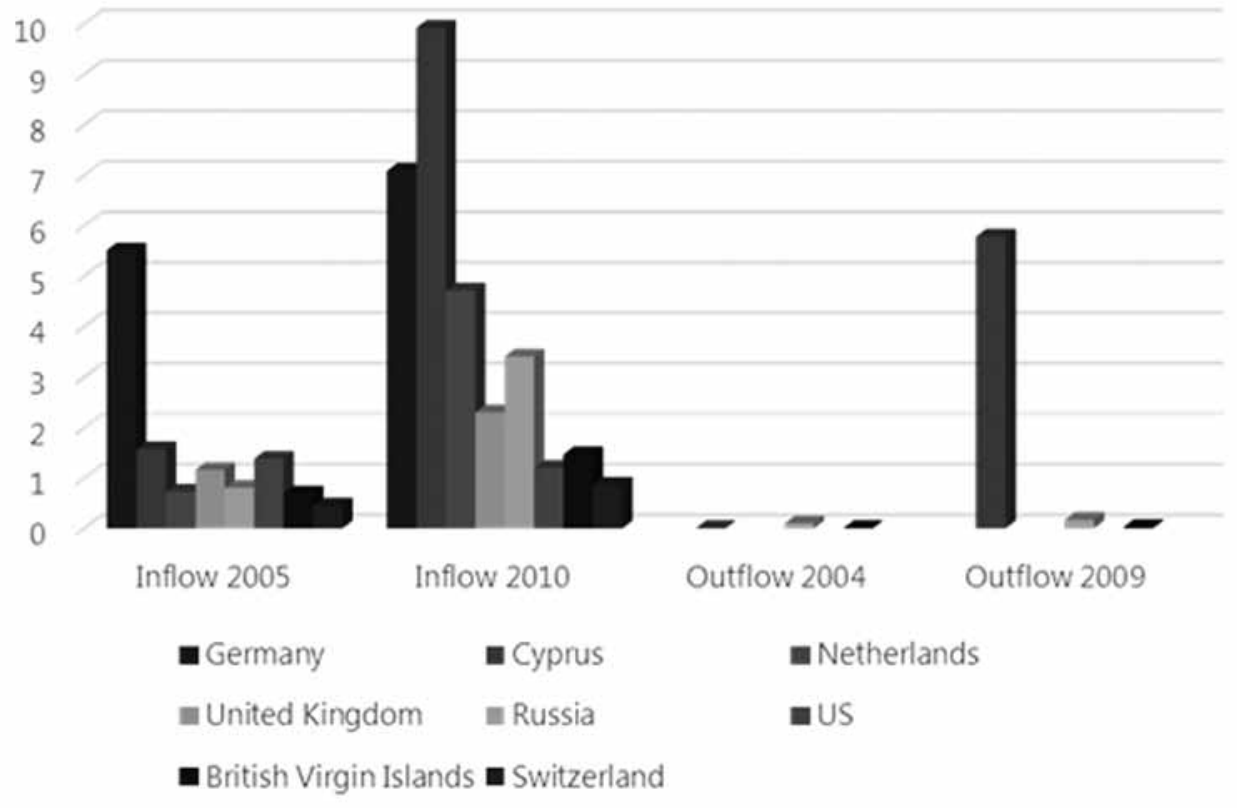

\section{UKRAINE}

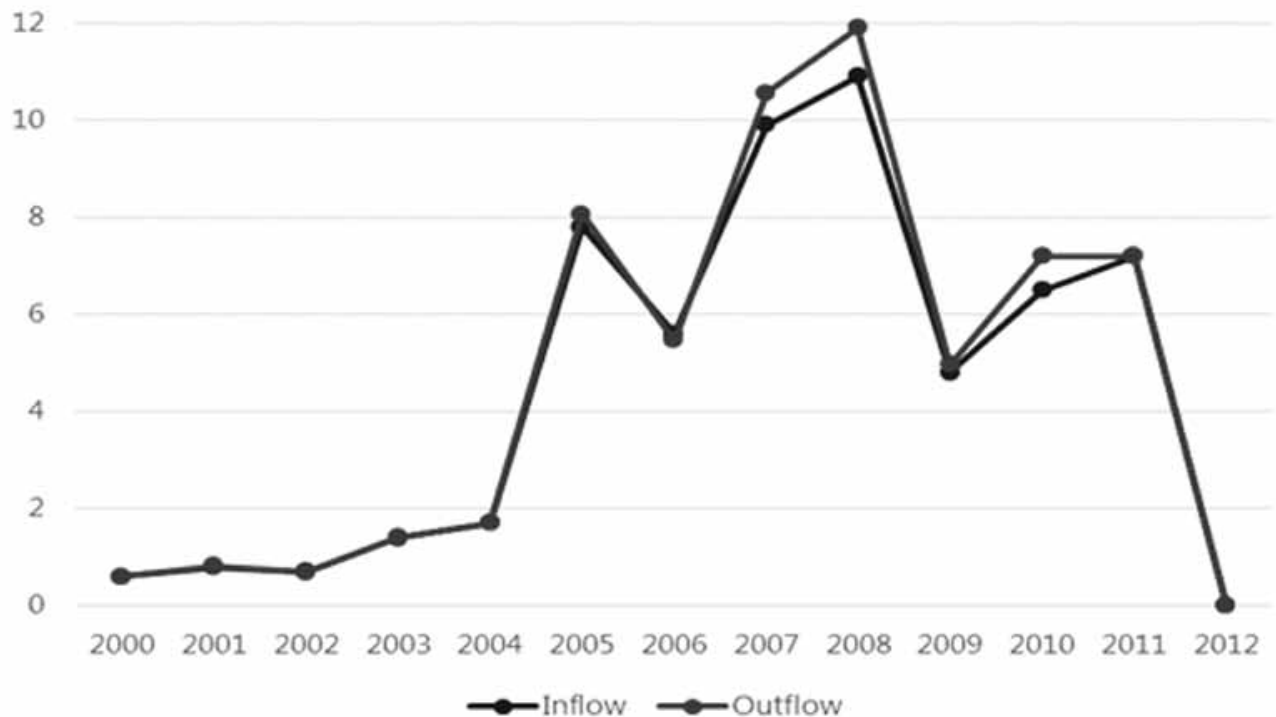

Megatrend revija Megatrend Review 


\section{SWITZERLAND FDI stock}

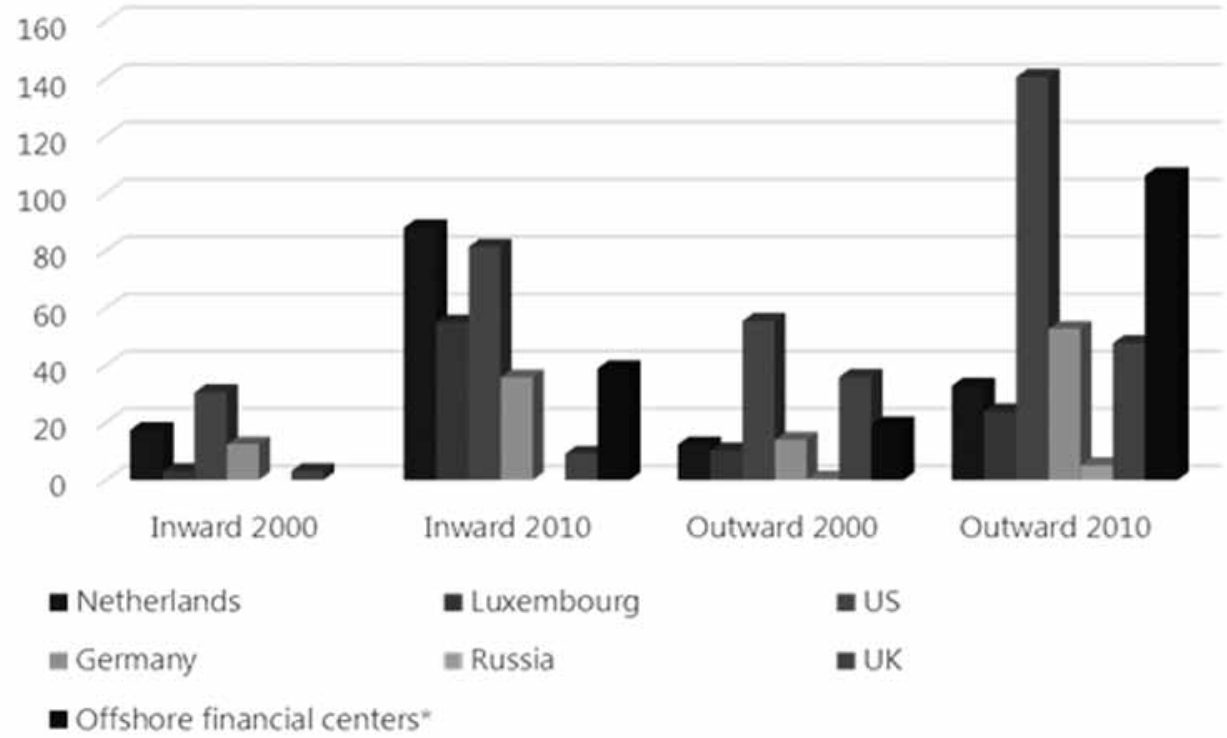

\section{SWITZERLAND}

120

100

80

60

40

20

0

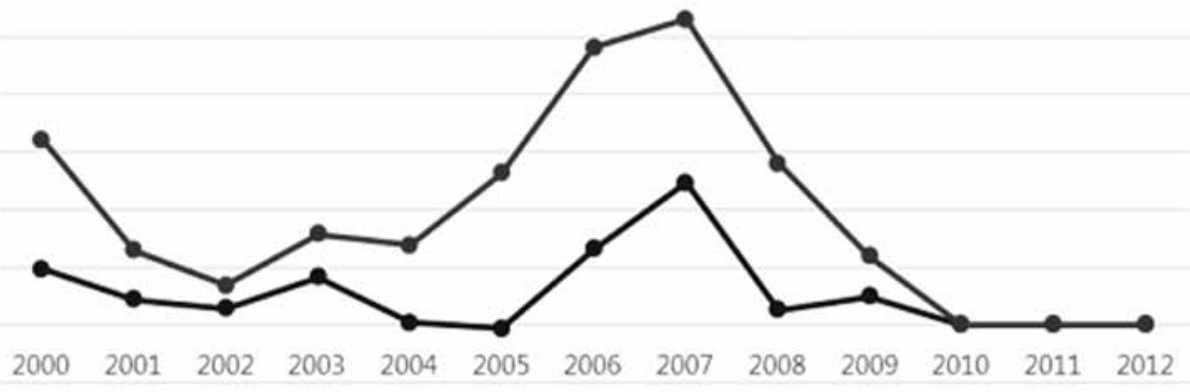

$\multimap$ Inflow $\rightarrow$ Outflow 
Anna Stepuk,

Viša ekonomska škola, Moskva, Rusija

\section{OFŠOR INVESTICIJE - CUI PRODIS? ŠREDINGEROVA MAČKA U OFŠOR FINANCIRANJU: I ŽIVA I MRTVA}

\section{S a ž e $\mathbf{t}$ a k}

Trendovi direktnih stranih investicija u ofšor poreskom raju upoređeni su sa naporima i efikasnošću regulatornih vlasti za sprečavanje pranja novca. $\mathrm{Na}$ osnovu raspoloživih podataka konstatovano je da je trenutna pozicija u ofšor FDI / DSI, u isto vreme živa i zvanično mrtva, održavajući balans interesa glavnih zainteresovanih strana: korporacija, vlasti i finansijskih institucija koje podržavaju daljnje ofšor investicije. Analiza je izvršena na osnovu količine trgovine i finansijskih transakcija između ofšor centara, razvijenih zemalja i zemalja u razvoju. Posledica povlačenja sredstava iz zemalja u razvoju je degradacija društvenih kapitalnih sredstava financiranja i pružanje podrške rastu korupcije.

Ključne reči: FDI / DSI direktne strane investicije, pranje novca, ofšor finansiranje, ofšor investicije, poreski raj 